\title{
PENGEMBANGAN MEDIA MONOPOLI EDUKATIF DI KELAS IV SEKOLAH DASAR
}

\author{
Zaky Ghufron, Goenawan Roebyanto, Sri Harmini \\ Universitas Negeri Malang, Jalan Semarang 5 Malang 65145 \\ Email: zakyghufron2@gmail.com
}

\begin{abstract}
This study aims to produce an educative monopoly media product that is valid according to the expert and effective according to the user. In addition, it is expected to improve student learning outcomes. Research methods used by researchers in research and development. This educative monopoly media is a modified research and development model by the researcher himself. The steps of research and development model are: (1) identification of needs; (2) product design; (3) production; (4) product validation; (5) product revisions; (6) trial usage; and (7) revision of the final product. After going through the steps of research and development, the researchers conducted an analysis of the data obtained. The results of the researcher's analysis show that this educative monopoly media is very effective in attracting students' attention to learn and very effective in improving the result of fourth grade student of Public Elementary School 4 Malang (SDN Pandanwangi 4 Malang). Based on the results of research and development of this educative monopoly media, it is expected that fourth grade teachers to use this educative monopoly media in learning, as well as maintaining and storing the media of educative monopoly well after using it. In addition, other researchers are also expected to test this educative monopoly media in other schools to see its effectiveness.
\end{abstract}

Keywords: learning media, educative monopoly, elementary school

\begin{abstract}
Abstrak: Penelitian ini bertujuan untuk menghasilkan sebuah produk media monopoli edukatif yang valid menurut ahli dan efektif menurut pengguna. Selain itu, diharapkan dapat meningkatkan hasil belajar siswa. Metode penelitian yang digunakan peneliti dalam penelitian dan pengembangan. Media monopoli edukatif ini yaitu model penelitian dan pengembangan hasil modifikasi oleh peneliti sendiri. Langkah-langkah model penelitian dan pengembangannya yaitu: (1) identifikasi kebutuhan; (2) desain produk; (3) produksi; (4) validasi produk; (5) revisi produk; (6) uji coba pemakaian; dan (7) revisi produk akhir. Setelah melalui langkah-langkah penelitian dan pengembangan, peneliti melakukan analisis terhadap data-data yang didapatkan. Hasil analisis peneliti menunjukkan bahwa media monopoli edukatif ini sangat efektif dalam menarik perhatian siswa untuk belajar serta sangat efektif dalam meningkatkan hasil belajar siswa kelas IV SDN Pandanwangi 4 Kota Malang. Berdasarkan hasil penelitian dan pengembangan media monopoli edukatif ini, diharapkan guru kelas IV untuk menggunakan media monopoli edukatif ini dalam pembelajaran, serta merawat dan menyimpan media monopoli edukatif dengan baik setelah menggunakannya. Selain itu, diharapkan juga peneliti lain mengujicobakan media monopoli edukatif ini di sekolah lain untuk melihat keefektifannya.
\end{abstract}

Kata kunci: media pembelajaran, monopoli edukatif, sekolah dasar

Media pembelajaran merupakan perantara yang menjadi penghubung dari pemberi informasi kepada penerima informasi. Pemanfaatan media pembelajaran dengan tepat akan dapat membantu siswa mencapai tujuan pembelajaran. Hal ini senada dengan pendapat Ibrahim (2006) yang menyatakan bahwa media pembelajaran adalah segala sesuatu yang dapat digunakan untuk menyalurkan 
pesan sehingga dapat merangsang perhatian, minat, pikiran dan perasaan siswa dalam belajar untuk mencapai tujuan pembelajaran tertentu. Siswa kelas IV sekolah dasar berusia antara 9 s.d. 11 tahun, pada usia ini siswa masih berada pada tahap operasional konkret. Sesuai dengan teori perkembangan Piaget yang menyatakan bahwa anak yang berusia antara 7 s.d. 11 tahun berada pada periode operasional konkret (Jauhar, 2011). Pada tahap operasional konkret, siswa mempunyai kemampuan proses berpikir untuk mengoperasikan kaidah-kaidah logika, namun terikat dengan objek yang bersifat konkret.

Oleh karena itu, pemanfaatan media pembelajaran yang bersifat konkret dapat membantu mengasah kemampuan berpikir siswa untuk mengoperasikan kaidah-kaidah logika. Jika guru tidak menggunakan media pembelajaran yang tepat, maka anak akan mengalami kesulitan dalam mencapai tujuan pembelajaran. Untuk mengetahui ketercapaian siswa pada pembelajaran 3 tema 5 Pahlawanku subtema 3 Sikap kepahlawanan, peneliti melakukan tes terhadap seluruh siswa kelas IV SDN Pandanwangi 4 Kota Malang sebanyak 33 siswa. Berdasarkan hasil tes terhadap seluruh siswa kelas IV SDN Pandanwangi 4 Kota Malang. Dari hasil tes tersebut, banyak siswa yang belum mencapai nilai kriteria ketuntasan minimal. Dari hasil tes tersebut dapat diketahui bahwa diperlukannya sebuah terobosan untuk memancing siswa agar tidak malas dengan pembelajaran yang terdapat muatan matematika didalamnya.

Peneliti menggunakan media monopoli edukatif sebagai solusinya. Penelitian dan pengembangan ini bertujuan untuk menghasilkan sebuah produk media monopoli edukatif yang valid menurut ahli dan efektif menurut pengguna. Selain itu, diharapkan dapat meningkatkan hasil belajar siswa Kelas IV Sekolah Dasar (SD) pada pembelajaran 3 tema 5 Pahlawanku subtema 5.3 Sikap Kepahlawanan.

\section{METODE}

Metode penelitian dan pengembangan yang digunakan peneliti dalam penelitian dan pengembangan media monopoli edukatif ini yaitu model penelitian dan pengembangan hasil modifikasi oleh peneliti sendiri. Langkah-langkah model penelitian dan pengembangannya yaitu: (1) identifikasi kebu- tuhan; (2) desain produk; (3) produksi; (4) validasi produk; (5) revisi produk; (6) uji coba pemakaian; dan (7) revisi produk akhir.

\section{Prosedur Penelitian}

Pada tahap awal penelitian dan pengembangan, peneliti menganalisis kebutuhan dan masalahmasalah pembelajaran di sekolah dasar, khususnya tentang penggunaan media pembelajaran di kelas IV SDN Pandanwangi 4 Kota Malang.Pada tahap kedua, peneliti merancang desain sebuah media monopoli edukatif untuk mengembangkan media pembelajaran. Pada tahap ketiga, peneliti membuat sebuah media monopoli edukatif sesuai dengan desain yang dibuat sebelumnya.Pada tahap keempat, peneliti menguji validitas media monopoli edukatif kepada ahli media dan ahli materi.Pada tahap kelima, data-data kualitatif berupa kritik dan saran dari ahli media dan ahli materi terhadap kualitas isi, kualitas instruksional, dan kualitas teknis media monopoli edukatif pada angket terbuka digunakan sebagai alat pertimbangan untuk merevisi desain media.Pada tahap keenam, peneliti mengujicobakan media pembelajaran monopoli edukatif di kelas IV SDN Pandanwangi 4 Kota Malang.

Langkah-langkah yang dilakukan peneliti pada tahap ini yaitu: (1) bekerjasama dengan guru dan siswa kelas IV SDN Pandanwangi 4 Kota Malang untuk melaksanakan pembelajaran 3 tema 5 subtema 3; dan (2) meminta guru dan siswa kelas IV SDN Pandanwangi 4 Kota Malang untuk mengisi angket evaluasi media monopoli edukatif. Dan pada tahap terakhir, peneliti mempertimbangkan data-data yang diperoleh melalui angket yang diisi oleh guru dan siswa kelas IV SDN Pandanwangi 4 Kota Malang untuk menyempurnakan produk akhir. Peneliti akan melakukan perbaikan pada media monopoli edukatif sesuai dengan angket yang diisi oleh guru dan siswa kelas IV SDN Pandanwangi 4 Kota Malang.

\section{Uji Coba Produk}

Uji coba produk dimaksudkan untuk mengumpulkan data yang digunakan sebagai dasar untuk menetapkan tingkat keefektifan, efisiensi, atau daya tarik produk yang dihasilkan (Suparno, 2010). Pada tahap ini secara berurutan akan dike- 
mukakan desain uji coba, subjek uji coba, instrumen pengumpulan data, dan teknik analisis data. Desain uji coba digunakan untuk memperoleh data yang dibutuhkan untuk mengevaluasi dan merevisi produk. Pada desain uji coba media monopoli edukatif, peneliti menggunakan uji coba ahli media, ahli materi, guru kelas IV SDN Pandanwangi 4 Kota Malang, dan siswa kelas IV SDN Pandanwangi 4 Kota Malang.

Subjek penelitian dan pengembangan yang terlibat dalam pengambilan data untuk penelitian dan pengembangan media monopoli edukatif yaitu: (1) ahli media; (2) ahli materi; (3) guru kelas IV SDN Pandanwangi 4 Kota Malang; dan (4) siswa kelas IV SDN Pandanwangi 4 Kota Malang. Instrumen pengumpulan data pada penelitian dan pengembangan media monopoli edukatif ini yaitu: (1) angket validasi ahli media; (2) angket validasi ahli materi; (3) angket validasi guru kelas; (4) angket validasi siswa kelas IV; dan (5) hasil pre-test dan post-test. Teknik analisis data yang digunakan oleh peneliti dalam penelitian dan pengembangan media monopoli edukatif ini yaitu teknik deskriptif kualitatif, analisis statistik deskriptif, dan analisis statistik inferensial non parametris.

Untuk mengukur tingkat validitas media monopoli edukatif dari ahli media dan ahli materi, peneliti menggunakan sebuah rumus. Rumus yang digunakan untuk mengolah data kuantitatif yang diperoleh dari angket tertutup ahli media dan ahli materi yaitu:

$$
\mathrm{V}=\frac{\mathrm{TSEV}}{\text { Skor maks }} \times 100
$$

\section{Keterangan:}

V : Validitas

TSEV : Total skor empirik validator

Skor maks : Skor maksimal yang diharapkan (Akbar, 2013)

Untuk mempermudah menarik kesimpulan dari hasil analisis data kuantitatifberupa persentase, peneliti menggunakan Tabel 1.

Tabel 1 Tabel Ketercapaian Validitas Produk

\begin{tabular}{ccl}
\hline No & Kriteria & \multicolumn{1}{c}{ Tingkat Validitas } \\
\hline 1 & $85,01 \%-100 \%$ & $\begin{array}{l}\text { Sangat valid, atau dapat } \\
\text { digunakan tanpa revisi }\end{array}$ \\
2 & $65,01 \%-85 \%$ & $\begin{array}{l}\text { Valid, atau dapat } \\
\text { digunakan namun perlu } \\
\text { revisi kecil }\end{array}$
\end{tabular}

\begin{tabular}{ccl}
\hline No & Kriteria & \multicolumn{1}{c}{ Tingkat Validitas } \\
\hline 3 & $40,01 \%-65 \%$ & $\begin{array}{l}\text { Kurang valid, disarankan } \\
\text { tidak dipergunakan karena } \\
\text { perlu revisi besar } \\
\text { Tidak valid, atau tidak } \\
\text { boleh dipergunakan }\end{array}$ \\
& $0 \%-40 \%$ &
\end{tabular}

Sumber: Adaptasi Akbar (2013)

Kemudian untuk mengukur tingkat keefektifan media monopoli edukatif dari guru dan siswa kelas IV SDN Pandanwangi 4 Kota Malang, peneliti juga menggunakan sebuah rumus. Rumus yang digunakan hampir sama dengan rumus yang digunakan peneliti untuk mengukur validitas dari ahli media dan ahli materi, yaitu:

$$
\mathrm{E}=\frac{\mathrm{TSEU}}{\text { Skor maks }} \times 100
$$

\section{Keterangan:}

$\begin{array}{ll}\text { E } & \text { : Efektifitas } \\ \text { TSEV } & : \text { Total skor empirik } \text { user } \\ & \text { (pengguna) }\end{array}$

Skor maks : Skor maksimal yang diharapkan $100 \% \quad$ : Bilangan konstanta

(Akbar, 2013)

Untuk mempermudah menarik kesimpulan dari hasil analisis data kuantitatif berupa persentase, peneliti menggunakan Tabel 2.

Tabel 2 Tabel Ketercapaian Efektifitas Produk

\begin{tabular}{ccc}
\hline No & Kriteria & Tingkat Efektifitas \\
\hline 1 & $85,01 \%-100 \%$ & Sangat Efektif \\
2 & $65,01 \%-85 \%$ & Efektif \\
3 & $40,01 \%-65 \%$ & Kurang Efektif \\
4 & $0 \%-40 \%$ & Tidak Evektif \\
\hline Sumber: Adaptasi Akbar (2013) &
\end{tabular}

Statistik inferensial nonparametris digunakan untuk mengevaluasi tingkat keefektifan media monopoli edukatif dalam meningkatkan ketuntasan hasil belajar pembelajaran 3 tema 5 Pahlawanku, subtema 5.3 Sikap Kepahlawanan siswa kelas IV SD yaitu mencapai nilai KKM 75. Guna mengetahui tingkat keefektifan media monopoli edukatifdalam meningkatkan ketuntasan hasil belajar siswa kelas IV SD, digunakan rumus uji McNemar test, uji dua pihak. Uji McNemar test dilakukan untuk mengetahui ada tidaknya perubahan ketuntasan hasil belajar siswa kelas IV SD yang signifikan antara sebelum dan setelah menggunakan media monopoli edukatif. Berikut rumus uji McNemar test untuk pengujian hipotesis uji dua pihak dengan 
batas penerimaan $\mathrm{H}_{\mathrm{o}}$ pada tingkat signifikansi $1 \%$ atau tingkat kepercayaan 99\%.

$$
\mathrm{Z}=\frac{\mathrm{D}-\mathrm{A}}{\sqrt{\mathrm{D}+\mathrm{A}}} \text {, batas penerimaa } 2,58
$$

\section{Keterangan:}

$\mathrm{Z}=$ Nilai deviasi normal $\mathrm{z}$

$\mathrm{A}=$ Jumlah siswa yang mencapai ketuntasan hasil belajar pada pretest tetapi tidak mencapai ketuntasan hasil belajar pada posttest

$\mathrm{D}=$ Jumlah siswa yang tidak mencapai ketuntasan hasil belajar pada pretest tetapi mencapai ketuntasan hasil belajar pada posttest (George, 1987)

Hipotesis yang diajukan yaitu:

Ho : Tidak ada perubahan ketuntasan hasil belajar pembelajaran 3 tema 5 Pahlawanku, subtema 5.3 Sikap Kepahlawanan siswa kelas IV SD yang signifikan setelah menggunakan media monopoli edukatif

$\mathrm{Ha}$ : Ada perubahan ketuntasan hasil belajar pembelajaran 3 tema 5 Pahlawanku, subtema 5.3 Sikap Kepahlawanan siswa kelas IV SD yang signifikan setelah menggunakan media monopoli edukatif

\section{HASIL}

Berdasarkan data uji ahli media, jumlah skor keseluruhan yang diperoleh sebanyak 63, terdiri dari 12 items yang mendapat skor 4 dan 5 item yang mendapat skor 3. Sedangkan skor maksimal yang bisa diperoleh yaitu 68, sehingga jika dipersentasekan menjadi 92,65\%. Perolehan persentase ini telah memenuhi kriteria skor validitas media sangat valid, yaitu antara persentase skor $85,01 \%$ s.d. $100 \%$. Validator mengatakan bahwa bidak pada permainan monopoli edukatif yang dibuat peneliti kurang sesuai dengan tema. Validator memberikan saran untuk mengganti gambar bidak menjadi gambar-gambar yang sesuai dengan tema (tema 5 Pahlawanku), bukan gambar doraemon.

Berdasarkan data uji ahli materi 1, jumlah skor keseluruhan yang diperoleh sebanyak 56, terdiri dari 5 items yang mendapat skor 4 dan 12 item yang mendapat skor 3. Sedangkan skor maksimal yang bisa diperoleh yaitu 68 , sehingga jika dipersentasekan menjadi 82,35\%. Perolehan persentase ini telah memenuhi kriteria skor validitas media valid, yaitu antara persentase skor $65,01 \%$ s.d. $85 \%$. Pada kolom saran validator menyatakan untuk mempertajam gambar dan memperjelas kata-kata.

Berdasarkan data uji ahli materi 2, jumlah skor keseluruhan yang diperoleh sebanyak 62, terdiri dari 11 items yang mendapat skor 4 dan 6 item yang mendapat skor 3. Sedangkan skor maksimal yang bisa diperoleh yaitu 68, sehingga jika dipersentasekan menjadi 91,18\%. Perolehan persentase ini telah memenuhi kriteria skor validitas media sangat valid, yaitu antara persentase skor 85,01\%-100\%. Pada kolom saran validator menyatakan untuk memperjelas kalimat latihan soal pada kartu kesempatan supaya siswa kelas IV sekolah dasar lebih mudah memahami.

Berdasarkan data uji ahli materi 3, jumlah skor keseluruhan yang diperoleh sebanyak 48, terdiri dari 9 items yang mendapat skor 4 dan 4 item yang mendapat skor 3 . Sedangkan skor maksimal yang bisa diperoleh yaitu 52, sehingga jika dipersentasekan menjadi 92,31\%. Perolehan persentase ini telah memenuhi kriteria skor validitas media sangat valid, yaitu antara persentase skor $85,01 \%-100 \%$. Pada kolom saran validator menyatakan untuk mengganti soal-soal yang masih ekonik dengan soal-soal yang simbolik.

Berdasarkan data uji coba guru, jumlah skor keseluruhan yang diperoleh sebanyak 57, terdiri dari 6 items yang mendapat skor 4 dan 11 item yang mendapat skor 3. Sedangkan skor maksimal yang bisa diperoleh yaitu 68 , sehingga jika dipersentasekan menjadi $83,82 \%$. Perolehan persentase ini telah memenuhi kriteria skor evaluasi media efektif, yaitu antara persentase skor $65,01 \%-85 \%$. Pada kolom saran guru kelas menyatakan untuk membuat latihan soal yang lebih menarik, supaya siswa mudah memahaminya.

Berdasarkan data uji coba siswa, jumlah skor keseluruhan yang diperoleh sebanyak 721 . Sehingga jika dipersentasekan menjadi 91,04\%. Perolehan persentase ini telah memenuhi kriteria skor evaluasi media sangat efektif. Pada kolom saran siswa menyatakan tidak ada saran, dan beberapa yang lain menuliskan tentang kesenangan mereka belajar dengan monopoli edukatif ini. Jadi peneliti menganggap tidak ada saran dari siswa. 
Berdasarkan data pe-test dan post-test, sebanyak 12 siswa tuntas dan 21 belum tuntas pada pretest. Sedangkan pada post-test, sebanyak 23 siswa berhasil tuntas dan hanya 10 siswa yang tidak tuntas. Berdasarkan perhitungan terhadap data frekuensi ketuntasan hasil belajar siswa Kelas IV SDN Pandanwangi 4 Kota Malang pada saat pre-test dan post-test dengan menggunakan rumus uji $\mathrm{Mc}$ Nemar test, diperoleh informasi bahwa harga $\mathrm{Z}_{\mathrm{Hitung}}$ $>$ harga kritis $\mathrm{z}$ (batas penerimaan $\mathrm{H}_{\mathrm{o}}$ ) atau 2,67 $>2,58$ sehingga $\mathrm{H}_{\mathrm{o}}$ ditolak dan $\mathrm{H}_{\mathrm{a}}$ diterima, dengan tingkat kepercayaan 99\%. Berdasarkan data tersebut dapat disimpulkan bahwa ada perubahan ketuntasan hasil belajar siswa Kelas IV SDN Pandanwangi 4 Kota Malang yang signifikan setelah menggunakan media monopoli edukatif. Dengan demikian, media monopoli edukatifterbukti efektif meningkatkan hasil belajar siswa kelas IV sekolah dasar pada pembelajaran 3 tema 5 pahlawanku, subtema 5.3 Sikap Kepahlawanan.

\section{Revisi Produk}

Berdasarkan saran dari ahli media untuk memperbaiki monopoli edukatif ini, peneliti merevisi desain bidak monopoli edukatif. Bidak yang sebelumnya bergambarkan kartun Doraemon, dan lain-lain diubah menjadi bidak bergambar animasi pahlawan. Berdasarkan saran dari ahli materi 1 untuk memperbaiki monopoli edukatif ini, peneliti merevisi kalimat-kalimat pada kartu materi. Peneliti memperjelas kata-kata pada kartu-kartu monopoli. Berdasarkan saran dari ahli materi 2 untuk memperbaiki monopoli edukatif ini, peneliti merevisi kalimat-kalimat latihan soal pada kartu kesempatan. Peneliti memperjelas kalimat-kalimat pada kartu kesempatan.

Saran dari ahli materi 3 yaitu mengubah soalsoal menjadi simbolik, bukan ekonik lagi. Saran dari Ahli materi 3 tidak peneliti gunakan untuk merevisi produk monopoli edukatif ini dengan alasan soal-soal yang ada pada media masih merupakan proses pemahaman kepada siswa, jadi masih menggunakan ekonik. Sedangkan soal-soal simbolik diberikan kepada siswa pada saat pretest dan post-test. Berdasarkan saran dari guru untuk memperbaiki monopoli edukatif ini, peneliti merevisi kalimat-kalimat latihan soal pada kartu hak milik. Peneliti membuat latihan soal menjadi lebih menarik. Tidak ada saran perbaikan dari siswa, karena memang pada kolom saran perbaikan mereka menuliskan tentang kesenangan mereka dalam bermain monopoli edukatif ini, ada juga yang menuliskan tidak ada. Jadi tidak ada revisi produk monopoli edukatif setelah evaluasi siswa.

\section{Kajian Produk Monopoli Edukatif yang Telah Direvisi}

Media monopoli edukatif merupakan produk yang berupa papan permainan dan kartu 2 dimensi, adaptasi dari papan permainan monopoli. Desain media monopoli edukatif seperti papan monopoli pada umumnya, namun dimodifikasi sesuai dengan tema 5. Pahlawanku dengan gambar-gambar animasi pahlawan supaya menjadi lebih menarik bagi siswa kelas IV sekolah dasar. Materi yang akan dimasukkan dalam media ini meliputi: teks ulasan, sikap cinta tanah air, dan penjumlahan dan pengurangan bilangan bulat. Media monopoli edukatif ini merupakan media pembelajaran dua dimensi yang berupa papan permainan. Satu set media monopoli edukatif terdiri dari satu papan monopoli berukuran 30 x $30 \mathrm{~cm}$, sebuah dadu, 5 buah bidak, 1 set kartu kesempatan,1 set dana umum, 1 set kartu hak milik, 1 set kartu voucher, 4 kartu materi, uang monopoli, kartu kunci jawaban, dan buku petunjuk bagi guru. Papan monopoli edukatif didesain selayaknya papan monopoli pada umumnya, namun banyaknya petak dikurangi menjadi 20 petak saja. Pertanyaan-pertanyaan terdapat pada kartu hak milik, kartu kesempatan, dan kartu dana umum.

\section{PEMBAHASAN}

Pembelajaran merupakan proses interaksi antara pendidik dan siswa, dengan si pendidik menyampaikan suatu pesan tertentu dan dengan cara tertentu agar siswa dapat mencapai tujuan yang telah ditetapkan. Jadi, perlu banyak keterampilan dari pendidik agar pembelajaran dapat berlangsung dengan baik. Hal ini selaras dengan Sudjana \& Rivai (2010) yang menyatakan proses pembelajaran merupakan suatu kegiatan melaksanakan kurikulum suatu lembaga pendidikan, agar dapat mempengaruhi para siswa mencapai tujuan pendidikan yang telah ditetapkan.

Media pembelajaran atau bahan pembelajaran merupakan sebuah alat yang dapat digunakan oleh guru untuk mempermudah menyampaikan pesan pembelajaran kepada siswa sehingga tujuan pemb- 
elajaran dapat tercapai. Seperti yang dinyatakan oleh Sudjana \& Rivai (2010) media pembelajaran adalah seperangkat materi keilmuan yang terdiri atas fakta, konsep, prinsip, generalisasi suatu ilmu pengetahuan yang bersumber dari kurikulum dan dapat menunjang tercapainya tujuan pembelajaran. Dari uraian tersebut dapat disimpulkan bahwa media pembelajaran merupakan komponen perantara materi yang dapat menghubungkan antara guru dengan siswa.

Siswa sekolah dasar (SD) umurnya berkisar antara 6 atau 7 tahun, sampai 12 atau 13 tahun. Menurut Piaget mereka berada pada fase operasional konkret (Heruman, 2014). Kemampuan yang tampak pada fase ini adalah kemampuan dalam proses berpikir untuk mengoperasikan kaidah-kaidah logika, meskipun masih terikat dengan objek yang bersifat konkret. Dilihat dari aspek perkembangan kognitif, menurut Piaget pada masa anak usia SD berada pada tahap operasi konkret, yang ditandai dengan kemampuan: (1) mengklasifikasikan (mengelompokkan) benda-benda berdasarkan ciri yang sama; (2) menyusun atau mengasosiasikan (menghubungkan atau menghitung) angka-angka atau bilangan; dan (3) memecahkan masalah (problem solving) yang sederhana (Yusuf dan Sugandhi, 2014).

Berdasarkan karakteristik siswa SD yang diuraikan Piaget tersebut, dapat disimpulkan anak usia SD masih berada pada tahapan operasional konkret. Pada masa ini dibutuhkan sebuah hal yang semikonkret untuk memudahkan siswa dalam memahami sesuatu, termasuk pada kelas tinggi. Guru dalam mengembangkan media pembelajaran harus memahami indikator dan tujuan pembelajaran (Gunawan dan Palupi, 2012). Kearifan lokal yang ada didaerah sekolah dapat digunakan untuk mengembangkan media pembelajaran (Gunawan, 2013; Gunawan, 2016). Menjadi tugas kepala sekolah agar para guru yang dipimpinnya menjadi guru kreatif serta inovatif dalam melaksanakan pembelajaran (Gunawan, 2015).

\section{SIMPULAN DAN SARAN}

Hasil analisis peneliti menunjukkan bahwa media monopoli edukatif ini sangat efektif dalam menarik perhatian siswa untuk belajar serta sangat efektif dalam meningkatkan hasil belajar siswa kelas IV SDN Pandanwangi 4 Kota Malang. Sa- ran yang diajukan bagi guru kelas IV diharapkan menggunakan media monopoli edukatif ini pada pembelajaran. Setelah menggunakan media monopoli edukatif, diharapkan pengguna merawatnya dengan baik. Saran pengembangan dari peneliti yaitu melakukan pengembangan produk di sekolah lain atau hanya melakukan eksperimen di sekolah lain untuk melihat keefektifan media monopoli edukatif di sekolah lain.

\section{DAFTAR RUJUKAN}

Akbar,S.2013.InstrumenPerangkatPembelajaran. Bandung: PT Remaja Rosdakarya.

Gunawan, I. 2013. Revitalisasi Karakter Guru menurut Filosofis Jawa: Sebuah Gagasan Mengembangkan Kepribadian Siswa. Proceeding International Seminar on: Local Wisdom and Character Education for Elementary School Students, IKIP PGRI MADIUN, hlm. 48-62.

Gunawan, I. 2015. Optimalisasi Peran dan Tugas Kepala Sekolah dalam Implementasi Kurikulum 2013. Prosiding Seminar Nasional Implementasi Kebijakan Ujian Nasional, Dualisme Kurikulum, dan Sistem Seleksi Masuk Perguruan Tinggi Negeri, Fakultas Ilmu Pendidikan Universitas Negeri Malang, hlm. 23-29.

Gunawan, I. 2016. Pasaran: Menggali Nilai-nilai Permainan Tradisional dalam Mengembangkan Sifat-sifat Kepemimpinan Pendidikan. Jurnal Studi Sosial, 8(1), hlm. 55-64.

Gunawan, dan Palupi, A. R. 2012. Taksonomi Bloom - Revisi Ranah Kognitif: Kerangka Landasan untuk Pembelajaran, Pengajaran, dan Penilaian. Premiere Educandu, 2(2), 98117.

Heruman. 2014. Model Pembelajaran Matematika di Sekolah Dasar. Bandung: PT Remaja Rosdakarya.

Ibrahim. 2006. Media Pembelajaran. Malang: Laboratorium Teknologi Pendidikan Universitas Negeri Malang.

Jauhar, M. 2011. Implementasi Paikem dari Behavioristik sampai Konstruktivistik. Jakarta: Prestasi Pustakaraya.

Sudjana, N., \& Rivai, A. 2010. Media Pengajaran (Penggunaan dan Pembuatannya). Bandung: Sinar Baru Algensindo. 